\title{
Effects of Naphthalene Acetic Acid (NAA) on Growth of Cosmos sulphureus
}

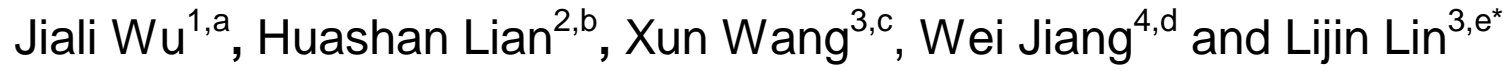 \\ ${ }^{1}$ College of Horticulture, Sichuan Agricultural University, Chengdu, Sichuan, China \\ ${ }^{2}$ Subcollege of Garden and Horticulture, Chendu Agricultural College, Chengdu, Sichuan, China \\ ${ }^{3}$ Institute of Pomology and Olericulture, Sichuan Agricultural University, Chengdu, Sichuan, China \\ ${ }^{4}$ College of Chemistry and Life Science, Chengdu Normal University, Chengdu, Sichuan, China \\ a1749272401@qq.com, b49939450@qq.com, '35744023@qq.com, d1399945180@qq.com, \\ ellj800924@163.com
}

${ }^{*}$ Corresponding author. Jiali Wu, Huashan Lian and Xun Wang contributed equally to this work.

Keywords: Naphthalene acetic acid; Cosmos sulphureus; Growth; Physiology

Abstract: A pot experiment was carried out to investigate the effects of applying naphthalene acetic acid (NAA) on growth and physiology of Cosmos sulphureus. The results showed that application of NAA promoted the growth of $C$. sulphureus when the dose of NAA was not more than $15 \mathrm{mg} / \mathrm{L}$. When the dose of NAA was lower than $15 \mathrm{mg} / \mathrm{L}$, the biomass, the contents of chlorophyll a, chlorophyll $\mathrm{b}$, total chlorophyll and carotenoid, the activities of SOD and POD, and the soluble sugar content of $C$. sulphureus increased, and got the maxima at the dose of $5 \mathrm{mg} / \mathrm{L}$ NAA. With the increase of concentration of NAA, the soluble protein and the CAT activity of $C$. sulphureus had the decreasing trend. Therefore, application of NAA could promote the growth of $C$. sulphureus at the dose of 5-15 $\mathrm{mg} / \mathrm{L}$.

\section{Introduction}

Naphthalene acetic acid (NAA) is one of plant hormones, which can regulate the growth and development of plants [1]. NAA extendes the storage time of the kiwi fruits [2] and red bayberry fruits [3]. When using different concentrations of NAA treat the hard branches of pyracantha, the number of roots increase, and the survival rates increase [4]. NAA treatment also promotes the rooting of Platanus orientalis [5]. The other studies also show that NAA promote the rooting of plants [6-9]. Howere, there are few studies on whether NAA could promote the growth of plants.

Cosmos sulphureus is one of annual herbaceous floricultural plants, origining from in Mexico [10]. In this study, we used the different concentrations of NAA to treat $C$. sulphureus, and studied the effects of NAA on growth and physiology of $C$. sulphureus. The aim of the study was to screen the best NAA concentration which could promote the growth of $C$. sulphureus, and provided a reference for applying the plant hormones on other floricultural plants.

\section{Materials and Methods}

Experimental Design. The nutrient soils and pearlites (2:1) were put into polyethylene pot $(15 \mathrm{~cm}$ high, $18 \mathrm{~cm}$ in diameter). Two uniform $C$. sulphureus seedlings with four euphyllas were transplanted into each pot in April 2016. When the plants grew to 10 euphyllas, 5 concentrations $(0,5,10,15$ and 20 $\mathrm{mg} / \mathrm{L}$ ) of NAA with 3 replicates were sprayed on the leaves of plants, respectively. The soil moisture was maintained at $80 \%$ of field capacity during the plant seedlings' growth process. At 60 days after planting (July 2016), the plants were harvested. The upper mature leaves of plants were collected to determine the photosynthetic pigment (chlorophyll $a$, chlorophyll $b$ and total chlorophyll) contents [11]. The upper young leaves $(2 \mathrm{~cm}$ in length) were collected to determine the superoxide dismutase (SOD) activity, peroxidase (POD) activity, catalase (CAT) activity and soluble protein content [11]. Then, the whole plants were then gently removed, the roots, stems and leaves were washed with tap 
water followed by deionized water, and the biomasses of root, stem and leaf were measured. The soluble sugar contents in roots, stems and leaves were determined by the anthrone colorimetry with dry weight plant samples [11].

Experimental Design. Statistical analyses were conducted using SPSS 13.0 statistical software (IBM, Chicago, IL, USA). Data were analyzed by one-way analysis of variance with least significant difference (LSD) at the $\mathrm{p}=0.05$ confidence level.

\section{Results and Discussion}

Biomass of $\boldsymbol{C}$. sulphureus. With the increase of NAA concentrations, the root, stem, leaf and shoot biomasses of $C$. sulphureus increased when the dose of NAA was not more than $5 \mathrm{mg} / \mathrm{L}$, and decreased when the dose of NAA was higher than $5 \mathrm{mg} / \mathrm{L}$ (Table 1). The order of root, stem, leaf and shoot biomasses of $C$. sulphureus were $5 \mathrm{mg} / \mathrm{L}$ NAA $>10 \mathrm{mg} / \mathrm{L}$ NAA $>15 \mathrm{mg} / \mathrm{L}$ NAA $>0 \mathrm{mg} / \mathrm{L}$ NAA $>20$ $\mathrm{mg} / \mathrm{L}$ NAA. When the dose of NAA was 5,10 and $15 \mathrm{mg} / \mathrm{L}$, the root biomass increased by $40.22 \%$ ( $P$ $<0.05), 35.60 \%(P<0.05)$ and $3.53 \%(P>0.05)$ respectively compared with the control, the stem biomass increased by $36.38 \%(P<0.05), 17.38 \%(P<0.05)$ and $12.54 \%(P<0.05)$ respectively compared with the control, the leaf biomass increased by $48.84 \%(P<0.05), 25.81 \%(P<0.05)$ and $9.07 \%(P<0.05)$ respectively compared with the control, and the shoot biomass increased by $41.80 \%$ $(P<0.05), 21.05 \%(P<0.05)$ and $11.03 \%(P<0.05)$ respectively compared with the control. So, When the dose of NAA was not more than $15 \mathrm{mg} / \mathrm{L}$, it could promote the growth of $C$. sulphureus.

Table 1 Biomass of $C$. sulphureus

\begin{tabular}{|c|c|c|c|c|}
\hline $\begin{array}{c}\text { Treatments } \\
(\mathrm{mg} / \mathrm{L})\end{array}$ & $\begin{array}{c}\text { Root biomass } \\
(\mathrm{g} / \text { plant})\end{array}$ & $\begin{array}{c}\text { Stem biomass } \\
(\mathrm{g} / \text { plant })\end{array}$ & $\begin{array}{c}\text { leaf biomass } \\
(\mathrm{g} / \text { plant })\end{array}$ & $\begin{array}{c}\text { Shoot biomass } \\
(\mathrm{g} / \mathrm{plant})\end{array}$ \\
\hline 0 & $3.68 \pm 0.103 \mathrm{~b}$ & $5.58 \pm 0.347 \mathrm{c}$ & $4.30 \pm 0.190 \mathrm{~cd}$ & $9.88 \pm 0.158 \mathrm{~d}$ \\
\hline 5 & $5.16 \pm 0.209 \mathrm{a}$ & $7.61 \pm 0.170 \mathrm{a}$ & $6.40 \pm 0.212 \mathrm{a}$ & $14.01 \pm 0.042 \mathrm{a}$ \\
\hline 10 & $4.99 \pm 0.252 \mathrm{a}$ & $6.55 \pm 0.214 \mathrm{ab}$ & $5.41 \pm 0.260 \mathrm{~b}$ & $11.96 \pm 0.045 \mathrm{~b}$ \\
\hline 15 & $3.81 \pm 0.191 \mathrm{~b}$ & $6.28 \pm 0.294 \mathrm{~b}$ & $4.69 \pm 0.182 \mathrm{c}$ & $10.97 \pm 0.112 \mathrm{c}$ \\
\hline 20 & $3.45 \pm 0.199 \mathrm{~b}$ & $5.30 \pm 0.235 \mathrm{c}$ & $3.90 \pm 0.086 \mathrm{~d}$ & $9.20 \pm 0.149 \mathrm{e}$ \\
\hline
\end{tabular}

Photosynthetic pigment content in $C$. sulphureus. The same as the biomass, the chlorophyll a, chlorophyll b, total chlorophyll and carotenoid contents of $C$. sulphureus increased when the dose of NAA was not more than $5 \mathrm{mg} / \mathrm{L}$, and decreased when the dose of NAA was higher than $5 \mathrm{mg} / \mathrm{L}$ (Table 2). The contents of chlorophyll a, chlorophyll $b$, total chlorophyll and carotenoid reached the maxmium when the dose of NAA was $5 \mathrm{mg} / \mathrm{L}$. When the dose of NAA was 5,10 and $15 \mathrm{mg} / \mathrm{L}$, the contents of chlorophyll a, chlorophyll b, total chlorophyll and carotenoid increased, and the dose of $20 \mathrm{mg} / \mathrm{L} \mathrm{NAA}$ decreased that. When the dose of NAA was 5,10 and $15 \mathrm{mg} / \mathrm{L}$, the chlorophyll a content increased by $24.31 \%(P<0.05), 19.23 \%(P<0.05)$ and $16.38 \%(P<0.05)$ respectively compared with the control, the chlorophyll b content increased by $21.51 \%(P>0.05), 17.60 \%(P>0.05)$ and $15.08 \%(P>0.05)$ respectively compared with the control, the total chlorophyll content increased by $23.63 \%(P<0.05)$, $18.84 \%(P<0.05)$ and $16.07 \%(P<0.05)$ respectively compared with the control, and the content of carotenoid increased by $23.08 \%(P<0.05), 18.72 \%(P<0.05)$ and $16.15 \%(P<0.05)$ respectively compared with the control. So, When the dose of NAA was not more than $15 \mathrm{mg} / \mathrm{L}$, it could improve the photosynthesis of $C$. sulphureus.

Soluble sugar content in $\boldsymbol{C}$. sulphureus. The application of NAA increased the soluble sugar contents in roots, stems, leaves and shoots of $C$. sulphureus (Table 3 ). With the increase of NAA concentrations, the soluble sugar contents in roots, stems, leaves and shoots of $C$. sulphureus had the increasing trend when the dose of NAA was not more than $5 \mathrm{mg} / \mathrm{L}$, and had the decreasing trend when the dose of NAA was higher than $5 \mathrm{mg} / \mathrm{L}$. The order of the soluble sugar contents in roots, stems, leaves and shoots of $C$. sulphureus were $5 \mathrm{mg} / \mathrm{L} \mathrm{NAA}>10 \mathrm{mg} / \mathrm{L} \mathrm{NAA}>15 \mathrm{mg} / \mathrm{L} \mathrm{NAA}>20 \mathrm{mg} / \mathrm{L}$ NAA $>0 \mathrm{mg} / \mathrm{L}$ NAA. When the dose of NAA was $5 \mathrm{mg} / \mathrm{L}$, the soluble sugar contents in roots, stems, 
leaves and shoots got the maxma, respectively. When the dose of NAA was 5, 10, 15 and $20 \mathrm{mg} / \mathrm{L}$, the soluble sugar contents in roots increased by 62.03\% $(P<0.05), 55.14 \%(P<0.05), 5.01 \%(P<0.05)$ and $1.88 \%(P>0.05)$ respectively compared with the control, the soluble sugar contents in stems increased by $41.10 \%(P<0.05), 39.36 \%(P<0.05), 34.93 \%(P<0.05)$ and $18.74 \%(P<0.05)$ respectively compared with the control, the soluble sugar contents in leaves increased by $106.13 \%(P<$ 0.05), 96.84\% $(P<0.05), 59.11 \%(P<0.05)$ and 52.60\% $(P<0.05)$ respectively compared with the control, and the soluble sugar contents in shoots increased by $54.35 \%(P<0.05), 51.19 \%(P<0.05)$, $41.30 \%(P<0.05)$ and $27.47 \%(P<0.05)$ respectively compared with the control. Therefore, NAA redistributed the soluble sugar in different organs of $C$. sulphureus.

Table 2 Photosynthetic pigment content in C. sulphureus

\begin{tabular}{|c|c|c|c|c|}
\hline $\begin{array}{c}\text { Treatments } \\
(\mathrm{mg} / \mathrm{L})\end{array}$ & $\begin{array}{c}\text { Chlorophyll a } \\
(\mathrm{mg} / \mathrm{g})\end{array}$ & $\begin{array}{c}\text { Chlorophyll b } \\
(\mathrm{mg} / \mathrm{g})\end{array}$ & $\begin{array}{c}\text { Total chlorophyll } \\
(\mathrm{mg} / \mathrm{g})\end{array}$ & $\begin{array}{c}\text { Carotenoid } \\
(\mathrm{mg} / \mathrm{g})\end{array}$ \\
\hline 0 & $1.123 \pm 0.060 \mathrm{~b}$ & $0.358 \pm 0.043 \mathrm{a}$ & $1.481 \pm 1.481 \mathrm{~b}$ & $0.39 \pm 0.390 \mathrm{ab}$ \\
\hline 5 & $1.396 \pm 0.024 \mathrm{a}$ & $0.435 \pm 0.014 \mathrm{a}$ & $1.831 \pm 1.831 \mathrm{a}$ & $0.480 \pm 0.480 \mathrm{a}$ \\
\hline 10 & $1.339 \pm 0.046 \mathrm{a}$ & $0.421 \pm 0.025 \mathrm{a}$ & $1.760 \pm 1.760 \mathrm{a}$ & $0.463 \pm 0.463 \mathrm{a}$ \\
\hline 15 & $1.307 \pm 0.013 \mathrm{a}$ & $0.412 \pm 0.026 \mathrm{a}$ & $1.719 \pm 1.719 \mathrm{a}$ & $0.453 \pm 0.453 \mathrm{a}$ \\
\hline 20 & $1.108 \pm 0.053 \mathrm{~b}$ & $0.351 \pm 0.019 \mathrm{a}$ & $1.459 \pm 1.459 \mathrm{~b}$ & $0.366 \pm 0.366 \mathrm{~b}$ \\
\hline
\end{tabular}

Table 3 Soluble sugar content in C. sulphureus

\begin{tabular}{|c|c|c|c|c|}
\hline $\begin{array}{c}\text { Treatments } \\
(\mathrm{mg} / \mathrm{L})\end{array}$ & $\begin{array}{c}\text { Roots } \\
(\mathrm{mg} / \mathrm{g})\end{array}$ & $\begin{array}{c}\text { Stems } \\
(\mathrm{mg} / \mathrm{g})\end{array}$ & $\begin{array}{c}\text { leaves } \\
(\mathrm{mg} / \mathrm{g})\end{array}$ & $\begin{array}{c}\text { Shoots } \\
(\mathrm{mg} / \mathrm{g})\end{array}$ \\
\hline 0 & $7.98 \pm 0.209 \mathrm{~d}$ & $13.77 \pm 0.253 \mathrm{~d}$ & $5.38 \pm 0.005 \mathrm{c}$ & $10.12 \pm 0.078 \mathrm{~d}$ \\
\hline 5 & $12.93 \pm 0.102 \mathrm{a}$ & $19.43 \pm 0.044 \mathrm{a}$ & $11.09 \pm 0.332 \mathrm{a}$ & $15.62 \pm 0.061 \mathrm{a}$ \\
\hline 10 & $12.38 \pm 0.208 \mathrm{~b}$ & $19.19 \pm 0.094 \mathrm{a}$ & $10.59 \pm 0.078 \mathrm{a}$ & $15.30 \pm 0.259 \mathrm{a}$ \\
\hline 15 & $8.38 \pm 0.177 \mathrm{~b}$ & $18.58 \pm 0.030 \mathrm{~b}$ & $8.56 \pm 0.144 \mathrm{~b}$ & $14.30 \pm 0.166 \mathrm{~b}$ \\
\hline 20 & $8.13 \pm 0.030 \mathrm{~cd}$ & $16.35 \pm 0.264 \mathrm{c}$ & $8.21 \pm 0.010 \mathrm{~b}$ & $12.90 \pm 0.024 \mathrm{c}$ \\
\hline
\end{tabular}

Antioxidant enzyme activity of $\boldsymbol{C}$. sulphureus. The application of NAA decreased the soluble protein content of $C$. sulphureus (Table 4). With the increase of NAA concentrations, the soluble protein content of $C$. sulphureus had the decreasing trend. When the dose of NAA was 5, 10, 15 and 20 $\mathrm{mg} / \mathrm{L}$, the soluble protein content decreased by $14.83 \%(P<0.05), 25.54 \%(P<0.05), 30.12 \%(P<$ $0.05)$ and $37.77 \%(P<0.05)$ respectively compared with the control. Different with the soluble protein content, when the dose of NAA was 5,10 and $15 \mathrm{mg} / \mathrm{L}$, the activities of SOD and POD improved, and $20 \mathrm{mg} / \mathrm{L}$ NAA reduced that (Table 4). When the dose of NAA was 5,10 and $15 \mathrm{mg} / \mathrm{L}$, the activity of SOD improved by $17.67 \%(P<0.05), 5.86 \%(P>0.05)$ and $1.02 \%(P>0.05)$ respectively compared with the control, and the activity of POD improved by $76.02 \%(P<0.05), 13.19 \%(P<0.05)$ and $10.43 \%(P<0.05)$ respectively. NAA reduced the activity of CAT, and the CAT activity of $C$. sulphureus had the decreasing trend with the increase of NAA concentrations (Table 4). When the dose of NAA was $5,10,15$ and $20 \mathrm{mg} / \mathrm{L}$, the soluble protein content decreased by $6.56 \%(P<0.05)$, $22.95 \%(P<0.05), 29.51 \%(P<0.05)$ and $47.54 \%(P<0.05)$ respectively compared with the control.

\section{Conclusions}

The application of NAA promoted the growth of $C$. sulphureus when the dose of NAA was not more than $15 \mathrm{mg} / \mathrm{L}$. When the dose of NAA was lower than $15 \mathrm{mg} / \mathrm{L}$, the biomass, the contents of chlorophyll a, chlorophyll b, total chlorophyll and carotenoid, the activities of SOD and POD, and the soluble sugar content of $C$. sulphureus increased, and got the maxima at the dose of $5 \mathrm{mg} / \mathrm{L}$ NAA. With the increase of concentration of NAA, the soluble protein and the CAT activity of $C$. sulphureus had the decreasing trend. Therefore, application of NAA could promote the growth of $C$. sulphureus at the dose of 5-15 mg/L. 
Table 4 Antioxidant enzyme activities of $C$. sulphureus

\begin{tabular}{|c|c|c|c|c|}
\hline $\begin{array}{c}\text { Treatments } \\
(\mathrm{mg} / \mathrm{L})\end{array}$ & $\begin{array}{c}\text { Soluble protein content } \\
(\mathrm{mg} / \mathrm{g})\end{array}$ & $\begin{array}{c}\text { SOD activity } \\
(\mathrm{U} / \mathrm{g})\end{array}$ & $\begin{array}{c}\text { POD activity } \\
(\mathrm{U} / \mathrm{g})\end{array}$ & $\begin{array}{c}\text { CAT activity } \\
{[\mathrm{mg} /(\mathrm{g} \cdot \mathrm{min})}\end{array}$ \\
\hline 0 & $6.54 \pm 0.14 \mathrm{a}$ & $253.84 \pm 5.07 \mathrm{~b}$ & $1011.15 \pm 14.14 \mathrm{c}$ & $0.061 \pm 0.002 \mathrm{a}$ \\
\hline 5 & $5.57 \pm 0.08 \mathrm{~b}$ & $298.70 \pm 10.08 \mathrm{a}$ & $1779.87 \pm 28.73 \mathrm{a}$ & $0.057 \pm 0.001 \mathrm{~b}$ \\
\hline 10 & $4.87 \pm 0.11 \mathrm{c}$ & $268.72 \pm 3.36 \mathrm{~b}$ & $1144.55 \pm 40.06 \mathrm{~b}$ & $0.047 \pm 0,002 \mathrm{c}$ \\
\hline 15 & $4.57 \pm 0.13 \mathrm{~d}$ & $256.43 \pm 6.65 \mathrm{~b}$ & $1116.62 \pm 19.34 \mathrm{~b}$ & $0.043 \pm 0.001 \mathrm{~d}$ \\
\hline 20 & $4.07 \pm 0.07 \mathrm{e}$ & $227.60 \pm 1.72 \mathrm{c}$ & $756.49 \pm 4.59 \mathrm{~d}$ & $0.032 \pm 0.002 \mathrm{e}$ \\
\hline
\end{tabular}

\section{Acknowledgements}

This work was financially supported by the 2016 Innovation Training Program of University Student (201610626032) and the Application Infrastructure Project of Science and Technology Department of Sichuan Province (2016JY0258).

\section{References}

[1] S.G. Mao, J.M. Xu and D.M. Li: Journal of Anhui Agricultural Sciences Vol. 45 (2006), p. 125.

[2] R.X. Yan, R.C. Wang and W.Q. Guan: Journal of Fruit Science Vol. 19 (2003), p. 206.

[3] Y. Xiao, J.C. Huang and H.B. Li: Journal of Southwest Agricultural University Vol. 21 (1999), p. 124.

[4] X.M. Zhou, B.Y. Li, J.W. Zhang and W.G. Yang: China Forestry Science and Technology Vol. 17 (2004), p. 112.

[5] J. Han, Q.J. Wu and W.S. Cui: Northern Horticulture Vol. 31 (2008), p. 130.

[6] F.L. Wang, H.G. Zhou, Z.F. Huang and Y.F. Liu: Chinese Agricultural Science Bulletin Vol. 24 (2008), p. 270.

[7] X.Y. Ye and H.W. Fan: Journal of Anhui Agricultural Sciences Vol. 48 (2009), p. 121.

[8] S.B. Liu, A. Luo, X. J. Jiang and X. Liu: Guizhou Agricultural Sciences Vol. 36 (2008), p. 154.

[9] D.M. L and X.J. Han: Modern Agricultural Science and Technology Vol. 36 (2008), p. 8.

[10] W. Lin, J. Li and S.Z Cai: Guangdong Agricultural Sciences Vol. 40 (2013), p. 39.

[11] Z.B. Hao, J. Chang and Z. Xu: Plant Physiology Experiment (Harbin Institute of Technology Press, China 2004). 